\title{
小特集 来る前に緊急地震速報が伝える
}

\section{2. 緊急地震速報の周知}

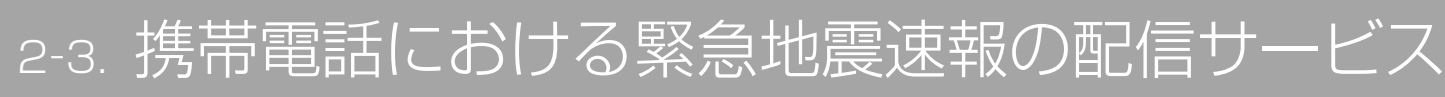

\section{今 井弘 ${ }^{\dagger}$}

キーワードロ 緊急地震速報，KDDI，携帯電話，ブロードキャストSMS，一斉配信，P波

\section{1 ま え がき}

気象庁が世界に先駆けて我が国で運用を開始した緊急地 震速報の配信は，2006年8月1日に公共機関や特定企業向け の先行的な提供が開始され, その後一般向けの本格運用に 向けた調査，検討が進められた後，2007年10月1日より一 般国民向けに配信が開始された.

KDDIでは，au携帯電話による携帯電話サービスを広く 国民の皆様へご提供しているが，国民一人1台の普及率に 近づきつつある最も身近な通信インフラとしての携帯電話 の重要性に鑑み, au携帯電話へ緊急地震速報を配信するシ ステムについて, 気象庁をはじめとする関係機関との調整, 検討を行い，システム開発を進めてきたが，2008年3月 25 日, au携帯電話への緊急地震速報配信サービスを開始する 運びとなった。

本稿では, au携帯電話における緊急地震速報配信システ
ムの概要について解説する(図1).

2 au携帯電話における一斉配信システムの 概要

\section{1 従来のメッセージ配信システム}

携帯電話におけるメッセージ配信システムとしては，従 来より電子メール (Eメールサービス) およびショートメッ セージサービス (SMS: au携帯電話におけるCメールサービ ス）が広く普及している.

近年，各種機関，自治体等により Eメールを利用した防 災・防犯・安全関連情報等を地域的に配信するサービスが 多く見られるようになってきたが，これらEメールもしく はCメールのメッセージ配信システムは，基本的に送信者 と受信者が1対1の関係でメッセージの送受を行う方式であ り，複数アドレスへの同報送信操作が可能なEメールであ っても，メールサーバと受信端末間では1対1のメッセージ

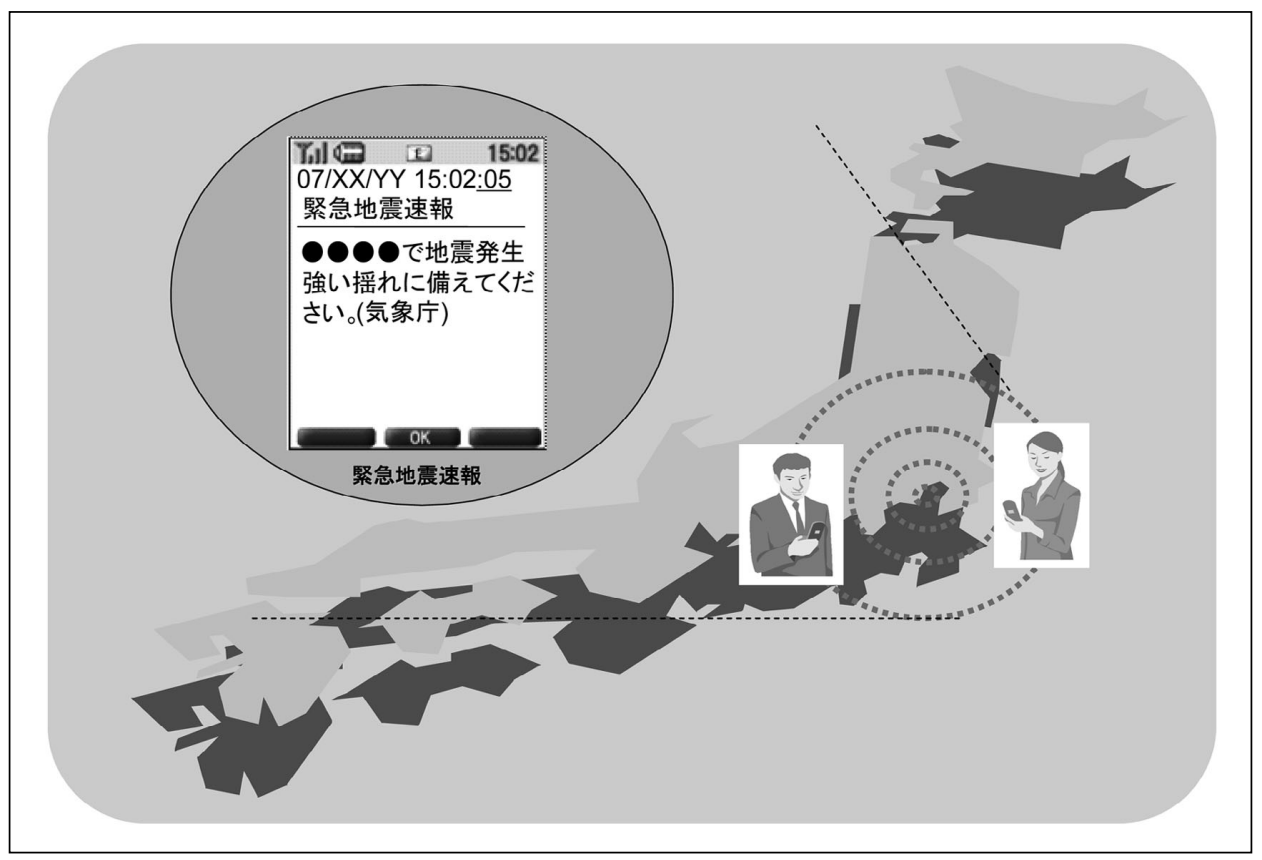

†KDDI株式会社 モバイルネットワーク開発本部

図1緊急地震速報イメージ図

"Earthquake Early Warning Service of Cellular Phone" by Hiroshi Imai (Head of General Administration Section "au" Technology Planning Department, Mobile Network Development Division, KDDI Corp., Tokyo) 


\section{配信が行われている.}

したがって，通信ネットワークが混み合っていない通常 の状態においては，比較的小さな遅延で受信者へメッセー ジが配信されるが，通信ネットワークが災害等の発生によ り輻輳（通信が非常に混み合って疎通が低下した状態）等が 発生した場合や，非常に多くの受信者宛てに同時にメッセ ージ配信を行った場合においては, 携帯電話端末と通信ネ ットワーク間において，多数の信号アクセスが同時に行わ れることとなり，通信ネットワーク容量を超える通信トラ フィックの発生となって, 受信者へのメッセージ配信が大 きく遅延する場合がある.

携帯電話への緊急地震速報の配信においては, たとえ災 害等による通信輻輳が発生している状況下であっても，携 帯電話端末を持った多数の受信者へ, 迅速かつ同時に情報 を伝えることが最も要求される条件の一つであることか ら, 従来のメッセージ配信システムとは異なる技術方式に より実現することとした。

\section{2 ブロードキャストSMS方式}

緊急地震速報の配信においては，3GPP2標準に規定され るブロードキャストSMS (B-SMS) 方式を用いた。本方式 の概要を図2に示す.

携帯電話システムにおいては, 各携帯電話端末は通常状 態において，ネットワーク側から報知される情報の中から 一定間隔ごとに自端末に割当てられた着信用スロットを監 視し, 電話やEメール等の着信の有無を判断しているが, B-SMSにおいては, 各端末へB-SMSのメッセージ配信を行 うことを通知した後, 受信する全端末へB-SMSメッセージ による緊急地震速報を一斉に配信する。この配信はネット ワーク側から携帯電話端末に向けての放送形式の一方向送 信であり，通常の電話やEメール等で行われる携帯電話端 末からネットワーク側へ向けた信号アクセスは行われな い. したがって, 通信ネットワークが例え輻軼等の状態に あっても, ネットワークへ通信トラフィックのインパクト を与えることなく, 対象地域の全携帯電話端末へ速報を配 信することが可能である.

\section{3 システム構成}

緊急地震速報は，気象庁が全国に設置した地震計によっ て検知される地震の初期微動 (P波) を迅速に解析し, 震源 地や予測震度，到達時間等を推定して警報配信するもので ある. KDDIでは, 緊急地震速報のうち, 複数箇所のP波情 報を基にして警報配信される一般向け緊急地震速報を受信 することにより，au携帯電話への緊急地震速報配信を行っ ている. システム構成を図3に示す。

気象庁が地震のP波を検出して緊急地震速報を発信する と，KDDIはBSDにて同速報を受信する，BSDは受信した 速報に含まれる地震発生予測地域情報を基に配信エリアを 決定し, au携帯電話へ配信するためのBroadcast SMSメッ セージを生成してSMSCへ送る.SMSCは受信した

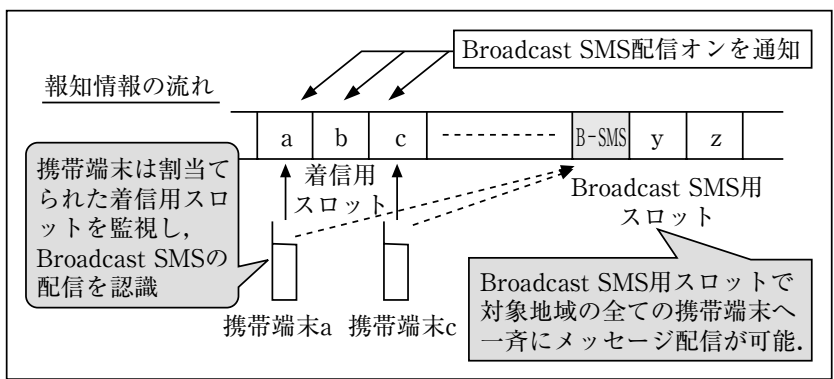

図2 ブロードキャストSMS方式によるメッセージ配信のイメージ

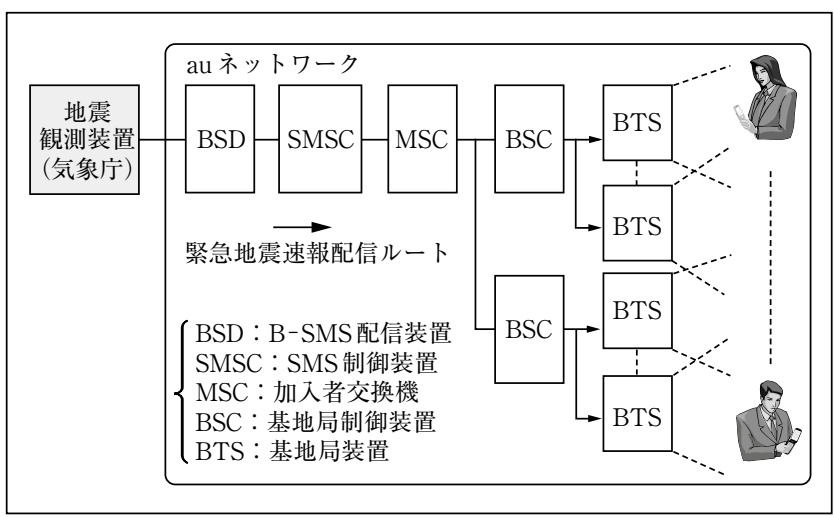

図3 システム構成

Broadcast SMSメッセージが “緊急地震速報”であることを 判断し，対象配信エリアへの配信を行うために制御情報と ともにメッセージ情報をMSCへ送る，MSCは制御情報を 基に“緊急地震速報”であることを判断し, 該当エリアの BSCに対しメッセージ送信を行う.メッセージを受信した 該当エリアのBSCは，配下の全BTSへ，該当エリア内に在 圈している(配信エリア内のBTSからの電波を受信可能な 状態にあること）全携帯電話端末に向けてB-SMSを送信し， BTSは受信したB-SMSメッセージを無線周波数に変換し て，携帯端末へ送信する。

\section{4 緊急地震速報の提供条件}

au携帯電話における緊急地震速報の提供条件を以下に示 す.

（1）対象となる携帯電話端末：緊急地震速報に対応した $\mathrm{au}$ 携帯電話端末 (2008年春より発売開始，2008年6月 上旬時点で 9 機種発売済, 8 機種発売予定）

(2) 配信対象となるご利用者：au携帯電話をお持ちで配 信対象エリア内に在圈するご利用者

(3) 配信対象エリア：最大震度5弱以上と推定した地震の 際に，強い摇れ(震度4以上) が予測される地域を気象 庁からの速報に含まれる予測地域情報に基づいて， 対応するau携帯電話ネットワークの配信対象エリア に変換して配信を行う。

（4）配信に要する時間：KDDIネットワークが情報を受信 してから携帯端末に到達するまで，できる限り早く 配信するものとする.

（5）利用者への通知方法：緊急地震速報専用の着信音 


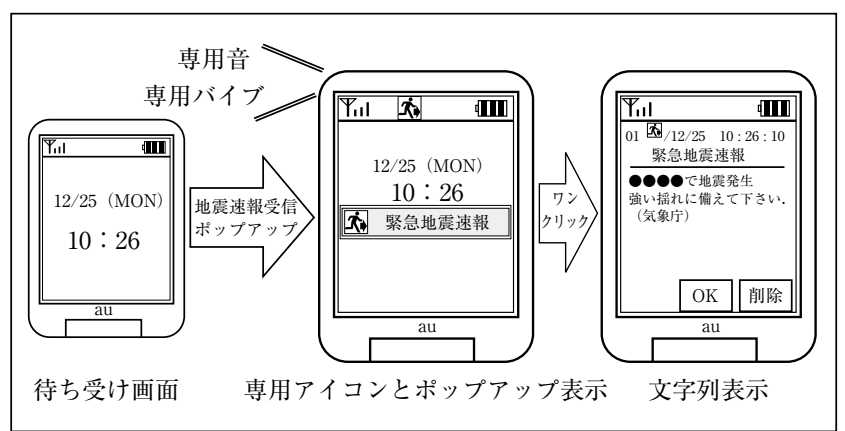

図4（a）＼cjkstart緊急地震速報受信時の画面表示の遷移

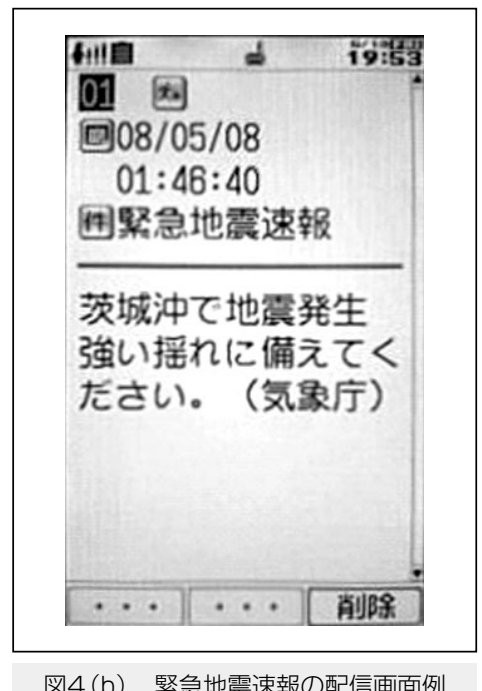

((株) NTTドコモ殿提供) およびバイブレータによる 振動. マナーモード設定時には, 専用報知音の鳴動 は停止するが，バイブレータ振動によりご利用者へ 通知を行う。

（6）配信情報の表示方法: 携帯電話端末が, 緊急地震速 報を受信した際は, 待ち受け画面上に緊急地震速報 専用のアイコンが表示され，受信したことが示され る。利用者がセンターボタンをワンクリックすると， Cメール相当の画面に文字列により緊急地震速報内容 が表示される (図4 (a)). 実際の画面表示を図4 (b)に 示す.

（7）付加機能等: 緊急地震速報は, 放送形式の一斉配信 メッセージであるが，表示形態等は現行のCメールと 類似しているため, au携帯端末においては, Cメール メニュー中に以下の付加機能を設けている.
(a) 受信ON/OFF設定
（b）専用報知音のモニ夕鳴動
(c) 受信履歴表示

\section{3 実際の配信状況と課題}

\section{1 実際の配信状況}

au携帯電話の緊急地震速報サービスを開始以降, 本稿執 筆時点 (2008年6月上旬) までに2回, 緊急地震速報の配信が
行われた

(1) 沖縄県宮古島近海を震源とする地震 2008年3月 28 日，02時32分（震源地における地震発生時 刻), 最大発生震度4.

KDDIが気象庁より一般向け緊急地震速報を受信した のは，02時32分25.6秒であり，直ちに宮古島および八 重山地区の au携帯電話に向けて緊急地震速報を発報. 現地の au携帯電話には，この数秒後に速報が到達.

(2) 茨城県沖を震源とする地震

2008年5月 8 日，01時45分（震源地における地震発生時 刻), 最大発生震度 5 弱.

KDDIが気象庁より一般向け緊急地震速報を受信した のは，01時46分32.8秒であり，直ちに宮城県，福島県， 群馬県, 栃木県, 茨城県, 埼玉県, 千葉県, 東京都, 神奈川県の au携帯電話に向けて緊急地震速報を発報. 現地の $\mathrm{au}$ 携帯電話には，この数秒後に速報が到達.

\section{2 今後の課題}

前項の緊急地震速報発報事例では，気象庁が警報発信す るまでに所要の時間を要しており, 実際の地震発生には残 念ながら間に合わなかったとの結果となっているが，到達 時間の適否については今後の議論や検討の余地はあるもの の，地震発生を予測する情報としての有意性および重要性 は充分示されたものと考えられる。

今後は，緊急地震速報が更にお客様の役に立つ情報とな るよう，通信事業者のネットワークや携帯電話端末におい ても, 必要な工夫や検討を進めたい。 また, 緊急地震速報 に対応した携帯電話機の機種拡大や対応機種の一層の普及 により，広く国民の皆様に役立つサービスとして発展させ ることが今後の課題である.

4 むす び

気象庁から送信される警報である緊急地震速報を，一斉 配信形式の新たな通信方式を用いて $\mathrm{au}$ 携帯電話へ配信する サービスの概要について解説した．国民全体の安全・安心 の確保に向け，今後とも本サービスの周知と利用拡大，対 応する携帯電話端末の更なる普及，ならびに本システムの 高度化や幅広い応用に向けての検討を進めたいと考える.

（2008年6月18日受付）

\section{〔文 献〕}

1）気象庁：“「緊急地震速報の本運用開始に係る検討会」最終報告” (Mar. 2007)

2) 3GPP2 : C.S0015-0 Broadcast SMS (TIA/EIA/IS- 637)

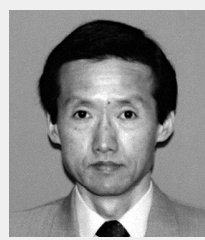

今告茀弘 1979年, 埼玉大学理工学部卒業. 1994年, 第二電電 (株) 入社. 以降，携帯電話ネットワ 一クの開発・標準化に従事. 2000年，KDD，DDI, IDOの3社合併によりKDDI (株) 設立。au技術本部技術 開発部課長. 2007年，モバイルネットワーク開発本部 au技術企画部総括グループリーダ. 